\section{Demonstrably wrong}

\author{
Public-private demonstration projects are a good way to test \\ technology in the field. But the driving force is often more \\ political than scientific, argues David Goldston.
}

\rceil he US government will spend about $\$ 2.4$ billion this fiscal year on applied research into energy efficiency and renewable sources, coal, oil, gas and nuclear energy. Much of the work will be done by researchers at national laboratories, but the most visible aspect of the US energy programme is demonstration projects - efforts jointly funded by the government and industry to test whether and how new technologies actually work in the field.

With their relatively large budgets, tangible facilities and corporate recipients, demo projects are ballyhooed by politicians and become rallying points for their communities, which benefit from the cash and jobs they bring. Demos tend to be the most politically secure yet substantively questionable activities in energy research and development.

There's perhaps no better illustration of the pitfalls of demonstration projects than the current brouhaha over FutureGen, the Bush administration's marquee demonstration project. FutureGen was proposed by the Department of Energy early in 2003 as a way to advance the president's climate technology and hydrogen initiatives. The plan called for building a new, state-of-the-art coal-burning electric plant that could capture its carbon dioxide emissions, which would be stored underground. The plant would also produce hydrogen gas and use it to generate additional electricity.

But this January, the Department of Energy abruptly announced that it was "restructuring" the project - actually cancelling it and replacing it with a programme to finance carbon capture and storage projects at privately built coal plants. The hydrogen aspect of the programme was dropped entirely. In explanation, the agency argued that the original project was becoming unsustainably costly and that the private sector was building more advanced coal plants on its own than had been expected five years ago.

Those are good reasons for cancelling FutureGen, but what really seems to have happened is that the coal industry for once overplayed its hand. In theory, industry is supposed to bear a sizable portion of the risk in demo projects after all, they are supposed to involve technology that is far along in its development and from which industry will directly benefit. If industry isn't willing to make a substantial commitment,

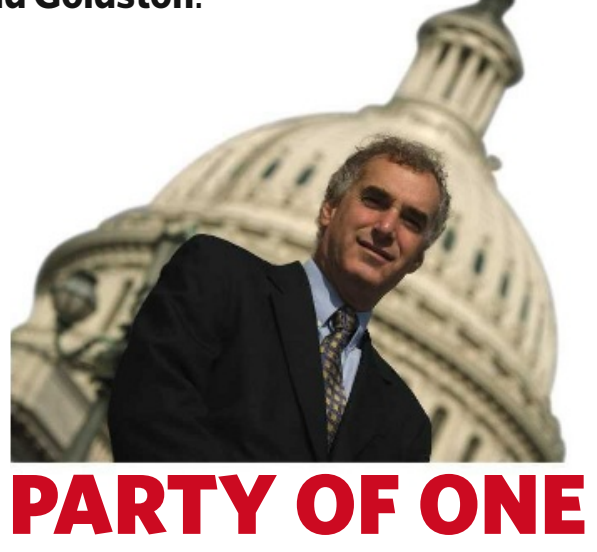

then that begs the question of whether the technology is truly ready for 'prime time. By law, the private sector is required to provide $50 \%$ of the funds for demo projects.

But that was never the case with FutureGen. The Department of Energy argued from the start that it wasn't a true demonstration but a "test bed", more of a way to research new technologies. As a result, the politically potent coal industry had to contribute just $20 \%$ to the project - later raised to $26 \%$. Last year, however, as the costs kept growing, the agency pressed the coal companies to pay $50 \%$ of the increases above the current $\$ 1.8$ billion price tag for the project. (The original cost estimate was $\$ 950$ million, but the two figures may not be comparable because they treat inflation differently.) The coal companies refused to budge, according to the agency, and they wanted to fund their share not with cash, but with debt leveraged against any money the plant would eventually make by selling electricity. This was apparently too galling even for the Department of Energy, and Secretary of Energy Samuel Bodman pulled the plug. Until that point, the agency had been negotiating in an attempt to find ways to continue the politically sensitive project it had touted so highly.

Not surprisingly, the main reaction in Congress has come from the congressional delegation from Illinois, the state where the FutureGen plant was to have been built. Indeed, the coal industry did everything possible to stoke the local politics. The site was chosen by industry, which announced the location in December, despite the Department of Energy's strenuous objections that doing so was premature. The Illinois delegation is numerous and powerful, and on a bipartisan basis it is fighting to keep the project alive. It's not clear whether anyone else in Congress will care enough to stop it. If nothing else, the delegation could prevent a final decision from being implemented until the next administration takes office, which could be headed by a President Obama from Illinois.

Ironically, while hoping for a home state saviour, some members of the Illinois delegation, including Senate Majority Whip Richard Durbin (Democrat, Illinois) are accusing the Bush administration of cancelling the project because Mattoon - the Illinois town that was to get the plant - won out over two potential sites in President Bush's home state of Texas. Representative John Shimkus (Republican, Illinois) said he personally pleaded with the president to save FutureGen, but was told "Bodman says the costs are too high".

All this, of course, begs the question of whether the project ever made sense to start with. Demonstration projects are often driven more by politics than by science. Small-scale, targeted demos can be a genuinely useful way to test out new technologies that are far enough along in their development stage. But FutureGen was to build an entire coal plant using fairly well tested technology and then add to it a mix of technologies, some of which may have needed more research, and some of which needed smaller, focused demonstrations. What FutureGen was really designed to show was that the administration and the coal industry were working on climate change, with the implication that it was too soon to force them to do anything.

Which brings us to FutureGen's fatal flaw, which it shares with many other energy technology projects. Research and development is a necessary, but hardly sufficient, component of an energy and climate policy. Without government steps to develop a market, such as a way to place a price on carbon, there is no reason for industry to pursue advanced technologies. Indeed, a rationale for the revised FutureGen proposal is that industry has no reason now to invest in carbon capture and storage technology, which makes coal plants less efficient and electricity more costly. The day after a House hearing last month to question the cancellation of FutureGen, the president gave a speech about climate change in which he basically attacked every current proposal to do more than just jawbone industry and fund scientists. In such a context, any energy demonstration project ought to be suspect. It will take a lot more political pressure to turn the administration's demo projects from coal black marks into diamonds.

David Goldston is a visiting lecturer at Harvard University's Center for the Environment. Reach him at partyofonecolumn@gmail.com. 